\section{A NEW RECORD OF AHERMATYPIC CORAL PARACYATHUS PRUINOSUS ALCOCK, 1902 (SCLERACTINIA: CARYOPHYLLIIDAE) FROM ANDAMAN AND NICOBAR ISLANDS, INDIA}

\section{R. Raghuraman ${ }^{1}$ \& C. Raghunathan ${ }^{2}$}

1,2 Zoological Survey of India, Andaman and Nicobar Regional Centre, National Coral Reef Research Institute, Port Blair 744102, Andaman and Nicobar Islands, India

${ }^{1}$ rtrp_26@yahoo.co.in (corresponding author),

${ }^{2}$ raghuksc@rediffmail.com

Azooxanthellate corals do not exhibit a symbiotic relationship with photosynthetic algae (zooxanthellae) and most of them are ahermatypic (non-reef building). Caryophylliidae is the largest family of azooxanthellate corals, comprising more than 300 species under 42 genera (Cairns 1999). In India, 12 species of Caryophylliidae are reported so far (Venkataraman et al. 2003), of which only three species: viz., Paracyathus indicus Duncan, 1899, P. profundus Duncan, 1889 and P. stokesii Milne Edwards \& Haime, 1848 are recorded from Indian coasts (Pillai 1972). The present record of Paracyathus pruinosus Alcock, 1902, at a depth range of 7-14 $\mathrm{m}$ in Andaman and Nicobar Islands is being reported herein as a new distributional record to India and the central Indian Ocean.
Materials and Methods: The samples of Paracyathus pruinosus were collected using SCUBA and field photographs were taken using Sony Cyber shot digital camera (Model: T900) with underwater housing, without causing undue damage to the colony. The specimens were

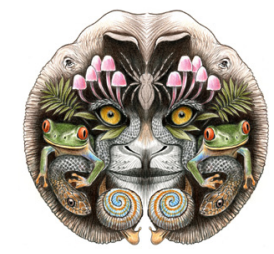

ISSN 0974-7907 (Online) ISSN 0974-7893 (Print)

\section{OPEN ACCESS} labelled and kept in freshwater for five days to remove the tissue. Adhered sticky gelatinous tissues if any, were cleaned using a strong jet of water. Detailed skeletal structures were studied and photographed under Labovison AXR20 compound microscope and Leica M205 stereo microscope. Specimens were deposited in the National Zoological Collections of the Zoological Survey of India (ZSI), Andaman and Nicobar Regional Centre (ANRC), Port Blair for future investigations.

Results: Phylum: Cnidaria Bourne, 1900; Class: Anthozoa Ehrenberg, 1831; Order: Scleractinia Hatschek, 1888; Family: Caryophylliidae Gray, 1847; Genus: Paracyathus Milne Edwards and Haime, 1848; Species: pruinosus Alcock, 1902

Material examined: Four specimens were collected from different localities of Andaman and Nicobar Islands.

ZSI/ANRC-8353, 23.i.2013, Rutland, Andaman Islands $\left(11^{0} 30.541^{\prime} \mathrm{N} \& 92^{0} 38.769^{\prime} \mathrm{E}\right)$; coll. R. Raghuraman; ZSI/ ANRC-8354, 11.xi.2012, South Button, Andaman Islands $\left(12^{\circ} 13.467^{\prime} \mathrm{N}\right.$ \& $\left.92^{\circ} 01.334^{\prime} \mathrm{E}\right)$, coll. R. Raghuraman;
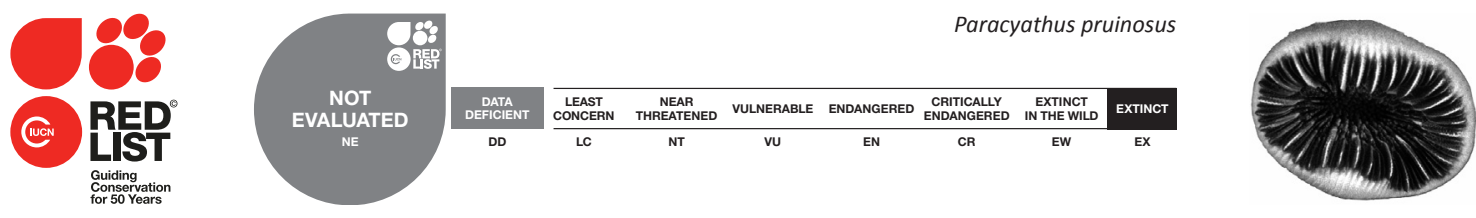

DOI: http://dx.doi.org/10.11609/jott.2470.7.15.8299-8301 | ZooBank: urn:Isid:zoobank.org:pub:DE68DE19-63BC-4DEC-A598-100E43DB80EO

Editor: M. Nithyanandan, Environmental Department, La Ala Al Kuwait Real Estate. Co. K.S.C., Kuwait. Date of publication: 26 December 2015 (online \& print) Manuscript details: Ms \# 03513 | Received 07 October 2013 | Final received 05 December 2015 | Finally accepted 11 December 2015

Citation: Raghuraman, R. \& C. Raghunathan (2015). A new record of ahermatypic coral Paracyathus pruinosus Alcock, 1902 (Scleractinia: Caryophylliidae) from Andaman and Nicobar Islands, India. Journal of Threatened Taxa 7(15): 8299-8301; http://dx.doi.org/10.11609/jott.2470.7.15.8299-8301

Copyright: @ Raghuraman \& Raghunathan 2015. Creative Commons Attribution 4.0 International License. JoTT allows unrestricted use of this article in any medium, reproduction and distribution by providing adequate credit to the authors and the source of publication.

Funding: The present study is a part of our routine coral surveys and is not funded by any agencies.

Conflict of Interest: The authors declare no competing interests.

Acknowledgements: The authors are grateful to the Director, Zoological Survey of India for the facilities.

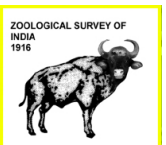



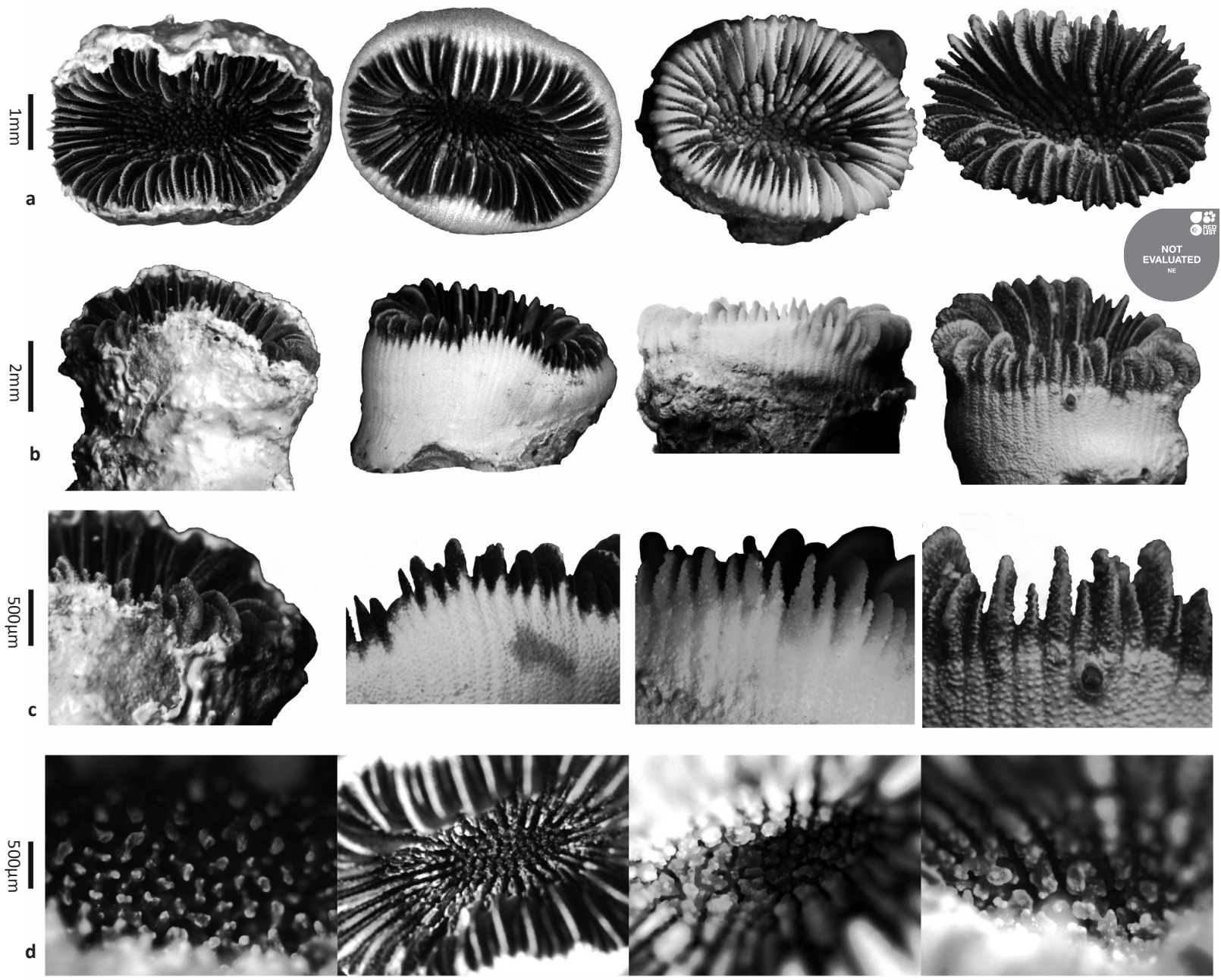

Image 1. Paracyathus pruinosus: a - Entire corallum of specimen; b - Lateral view of all specimens; c - Detail view of exsert septa; $d$ - Detail view of fossa.

ZSI/ANRC-8355, 10.ii.2012, Hut Bay, Andaman Islands $\left(10^{\circ} 55.830^{\prime} \mathrm{N} \& 92^{\circ} 07.023^{\prime} \mathrm{E}\right)$, coll. R. Raghuraman; ZSI/ ANRC-8356, 05.iv.2012, Nancowry, Nicobar Islands $\left(08^{\circ} 02.806^{\prime} \mathrm{N} \& 9^{\circ} 34.556^{\prime} \mathrm{E}\right)$, coll. R. Raghuraman.

Description: Corallites are solitary, short, stout, elliptical and solid, mostly found under caves; slightly deep (Image 1a); costae are granular, flat and equal (Image 1b). Septa are arranged closely and lined with granular ridges. S1 slightly exsert than others (Image 1c), straight to the collumella and lined with palus. S2 and S3 only slightly less exsert than primary septa, both covered with a small palar crown (Image 1d). Corallum is light brown in colour for deep water species and green in colour for the shallow water species. Tentacles extend only during night.

Discussion: The genus Paracyathus was first described by Milne Edwards and Haime (1848) with type specimen of Paracyathus procumbens. A total of 24 valid Paracyathus species are recorded all over the world (Carins et al. 2001). All four specimens of Paracyathus pruinosus from Andaman and Nicobar Islands were collected from shallow waters at depths ranging from 7-14 m. Number of septa $\left(\mathrm{S}_{\mathrm{n}}\right)$ of $P$. pruinosus increases along with GCD, LCD and height of the corallum was found to increase with the size of the corallite (Table 1). However, for the specimens from Soyo Maru (235m) off Japan, larger specimen was reported with 66 septa whereas the smaller one was reported with 70 septa (Carins 1994).

Literature surveys indicate that only $P$. indicus (van der Horst 1931) was reported from the Andaman Sea so far. The present record of $P$. pruinosus from Andaman and Nicobar Islands not only represents a new addition to the Caryophylliidae of the Central Indian Ocean, but also calls for conducting in-depth studies in the understudied caryophylliids of India. 
Table 1. Morphometric details of Paracyathus pruinosus Alcock, 1902 collected in Andaman and Nicobar islands.

\begin{tabular}{|l|c|c|c|c|}
\hline Register No. & GCD X LCD $(\mathrm{mm})$ & $\mathbf{C H}(\mathrm{mm})$ & $\mathbf{S}_{\mathrm{n}}(\mathrm{no})$. & Depth $(\mathrm{m})$ \\
\hline ZSI/ANRC-8353 & $18.4 \times 8.42$ & 1.12 & 82 & 9 \\
\hline ZSI/ANRC-8354 & $13.2 \times 9.86$ & 0.72 & 78 & 14 \\
\hline ZSI/ANRC-8355 & $10.02 \times 8.2$ & 0.48 & 66 & 8 \\
\hline ZSI/ANRC-8356 & $8.86 \times 7.8$ & 0.42 & 60 & 7 \\
\hline
\end{tabular}

GCD - Greater Corallite Diameter; LCD - Lesser Corallite Diameter; CH - Corallite Height; $\mathrm{S}_{\mathrm{n}}$ - Number of septa

\section{References}

Cairns, S.D. (1994). Scleractinia of the temperate North Pacific. Smithsonian Contribution to Zoology 557: 1-150.

Cairns, S.D. (1999). Species richness of recent Scleractinia. Atoll Research Bulletin 459: 1-46.

Cairns, S.D., B.W. Hoeksema \& J. van der Land (2001). Scleractinia, pp. 109-110. In: Costello, M.J. C. Emblow \& R.J. White (eds.). European Register of Marine Species: A Check-list of the Marine Species in Europe and A Bibliography of Guides to their Identification. Collection Patrimoines Naturels, 50.

Pillai, C.S.G. (1972). Stony corals of the seas around India. Proceedings of Symposium on Coral and Coral reefs. Marine Biological Association of India 191-216pp.

van der Horst (1931). Some solitary corals from the Indian Ocean. Records of the Indian Museum 38: 3-11.

Venkataraman, K., C. Satyanarayana, J.R.B. Alfred \& Wolstenholme (2003). Hand Book on Hard Corals of India. Zoological Survey of India, 266pp. 